\title{
Assessment of the Diversity of Large Tree Species in Rapidly Urbanizing Areas along the Chao Phraya River Rim, Central Thailand
}

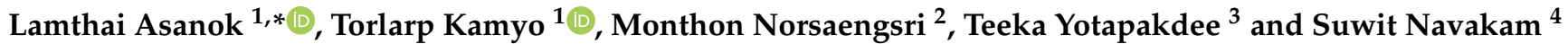 \\ 1 Department of Agroforestry, Maejo University, Phrae Campus, Phrae 54140, Thailand; torlarp66@gmail.com \\ 2 Department of Biology, Maejo University, Phrae Campus, Phrae 54140, Thailand; norsaengsri@gmail.com \\ 3 Department of Economic, Maejo University, Phrae Campus, Phrae 54140, Thailand; teekasom@gmail.com \\ 4 PTT Reforestation and Ecosystem Institute, PTT Public Company Limited, Bangkok 10900, Thailand; \\ suwit.n@pttplc.com \\ * Correspondence: lamthainii@gmail.com; Tel.: +66-89-014-5461
}

\section{check for} updates

Citation: Asanok, L.; Kamyo, T.; Norsaengsri, M.; Yotapakdee, T.; Navakam, S. Assessment of the Diversity of Large Tree Species in Rapidly Urbanizing Areas along the Chao Phraya River Rim, Central Thailand. Sustainability 2021, 13, 10342. https://doi.org/10.3390/ su131810342

Academic Editors: Paolo Semenzato and Thomas Campagnaro

Received: 17 August 2021

Accepted: 14 September 2021

Published: 16 September 2021

Publisher's Note: MDPI stays neutral with regard to jurisdictional claims in published maps and institutional affiliations.

Copyright: (c) 2021 by the authors. Licensee MDPI, Basel, Switzerland. This article is an open access article distributed under the terms and conditions of the Creative Commons Attribution (CC BY) license (https:// creativecommons.org/licenses/by/ $4.0 /)$.

\begin{abstract}
Urban trees provide numerous ecosystem services in cities such as pollution absorption and reduced urban heat island intensity, energy use, and mental fatigue. Understanding urban tree species diversity can enhance tree planning and management in rapidly urbanizing areas. However, few studies have examined the effects of urbanization on urban tree diversity in Thailand. This study assessed the diversity of large trees in urban landscapes including 11 cities along the $372 \mathrm{~km}$ Chao Phraya River Rim in central Thailand. Species diversity, importance value, and distribution were evaluated in each city. Our survey documented 987 large trees belonging to 65 species, 48 genera, and 31 families. The dominant species of Dipterocarpus alatus and Hopea odorata had the highest importance and relative abundance. The highest abundance of large trees was seen in the rural city of Sing Buri, while large urban cities such as Ayutthaya and Bangkok exhibited the highest species diversity. Detrended correspondence analysis indicated that the diversity of unique species was high in large urban cities, while dominant and common species were ubiquitous in rural cities. These findings suggest that large trees are few in number but exhibit high species diversity in large rapidly urbanizing cities. Therefore, preserving good site conditions is critical for the survival of large trees in urban cities. Heritage tree registration may aid preservation efforts and enhance the benefits of these large trees in rapidly urbanizing areas.
\end{abstract}

Keywords: tree composition; urban tree conservation; unique species; heritage tree; urban forestry

\section{Introduction}

The species diversity of urban trees is a key component of urban biodiversity [1,2]. High diversity is important for the resilience of urban trees, particularly under changing habitat and environmental conditions [3,4]. High tree diversity is associated with positive emotions and beneficial services, which fulfill important immaterial and non-consumptive human needs [5]. Urban trees benefit and improve environmental and ecological functions, as well as the socioeconomic status of urbanizing areas [6,7]. Several previous studies have identified key benefits of urban trees [8-11]. Urban tree diversity is also linked to territorial sustainability, resilience, and mitigation of the impacts of climate change [12]. Therefore, the species diversity of urban trees has numerous ecological impacts in urbanizing ecosystems. However, rapid urbanization can lead to losses in the habitat and diversity of urban trees [13], as continuous forest can be quickly transformed to small forest patches [14,15]. Rapid urbanization can also alter the micro-environmental conditions that limit tree growth in urban areas [16]. Urban tree habitats often include many limiting factors both aboveand below-ground [17]. For example, large cities have built-up areas that create soil compaction and extreme microclimates, which undermine urban tree health [18-20]. Thus, 
urban trees face numerous stressors, such as environmental degradation and physiological stress, which can reduce vitality and cause mortality [21]. Therefore, management and preservation of urban tree species diversity is key to maintaining good environmental conditions in rapidly urbanizing areas.

Large trees with distinct characteristics have always attracted attention in urban areas and are usually registered as heritage trees [17]. Heritage trees are those recognized to have valuable natural or cultural traits and often play an important role in the cultural landscape. Such trees have diverse characteristics such as advanced age ( $\geq 100$ years), large size (in terms of height, crown spread, or diameter at breast height [DBH]), distinctive forms, historical-cultural associations, and sacred, mythical connotations [17,22]. Heritage trees are irreplaceable due to their great preservation value and are significant due to their unique and historic contribution to community well-being [23]. The informed management and conservation of heritage trees through scientific surveys, citizen engagement, and assessments of economic value could improve community awareness of their multiple benefits [24,25]. Many countries have designated heritage trees in capital cities such as Beijing (China), Sydney (Australia), Tokyo (Japan), and Bangkok (Thailand) [26]. These heritage trees are valued for various reasons in different countries but are universally considered crucial for species diversity in urban landscapes. Assessing the species diversity of large trees in urbanized areas can provide data to support heritage tree registration.

The Thai government has encouraged the establishment of green areas, focusing on the conservation value of large trees in urbanized areas. In 2018, the Ministry of Natural Resources and Environment of Thailand promoted the urban forest project "Pracharat Forest Park for the happiness of the Thai people" to increase green areas within urbanized zones. These zones are now green spaces that serve as learning centers, recreation areas, and tourist attractions, reducing pollution and creating a suitable environment for creating happiness and well-being [27]. In the same year, the Ministry of Culture established the project "Tree of Siam natural treasure by the royal grace of His Majesty King Bhumibol Adulyadej" to increase the cultural conservation value of trees [28]. Thus, datasets describing large urban trees are required to support these nationally significant projects. The main urbanized region of Thailand is located along the $372 \mathrm{~km}$ Chao Phraya River Rim and includes 11 cities. The area is rapidly urbanizing as a major center of economic and social development in Thailand and includes the nation's largest cities: Bangkok and Ayutthaya (the former capital). Economic and urban sprawl are spreading rapidly from Bangkok to cities located along the Chao Phraya River. More than a century ago, much of this area's landscape was covered by riparian flood plain forest, but the urbanization process has reduced many forested areas to small forest patches and isolated trees [14,29]. As a result, large trees are scattered throughout the region, especially in the area along the Chao Phraya River Rim. However, very little data exist regarding these large trees; only one study has surveyed the largest trees in Bangkok Metropolitan Authority [30]. This paucity of research highlights the urgent need for assessments of the species diversity of large trees along the urbanizing region of the Chao Phraya River. To this end, the present study investigated the species diversity of large trees in urbanizing landscapes along the Chao Phraya River Rim in central urban Thailand. The primary objective was to provide more information on large trees in urbanizing areas in order to facilitate the conservation and management of urban trees in rapidly urbanizing parts of Thailand. The data from this study could also support the registration of heritage trees in Thailand.

\section{Materials and Methods}

\subsection{Study Area}

The study site is located along the Chao Phraya River Rim (50 m from the river on both the right and left banks), starting from the Pak Nam Pho sector of Nakhon Sawan $\left(15^{\circ} 41^{\prime} 52^{\prime \prime} \mathrm{N}, 100^{\circ} 9^{\prime} 21^{\prime \prime} \mathrm{E}\right)$ and ending in the Pak Nam sector of Samut Prakan $\left(13^{\circ} 32^{\prime} 18^{\prime \prime} \mathrm{N}\right.$, $\left.100^{\circ} 34^{\prime} 58^{\prime \prime} \mathrm{E}\right)$. The mean annual temperature and rainfall in the region are $28.5^{\circ} \mathrm{C}$ and $1338 \mathrm{~mm}$, respectively. The area experiences two main seasons: a wet season (May-October) 
and a dry season (November-April) [31]. The Chao Phraya River is the largest river in central Thailand, spanning a length of $372 \mathrm{~km}$ on a north-south axis through 11 cities (Figure 1). The upper portion of the river flows through the rural cities of Nakhon Sawan, Uthai Thani, Chai Nat, Sing Buri, Lop Buri, and Ang Thong, and the lower portion flows through the large urban cities of Ayutthaya, Pathum Thani, Nonthaburi, Bangkok, and Samut Prakan. The downstream cities are rapidly expanding and urbanizing due to governmental expansion policies designed to create a commercial hub in Southeast Asia [32].

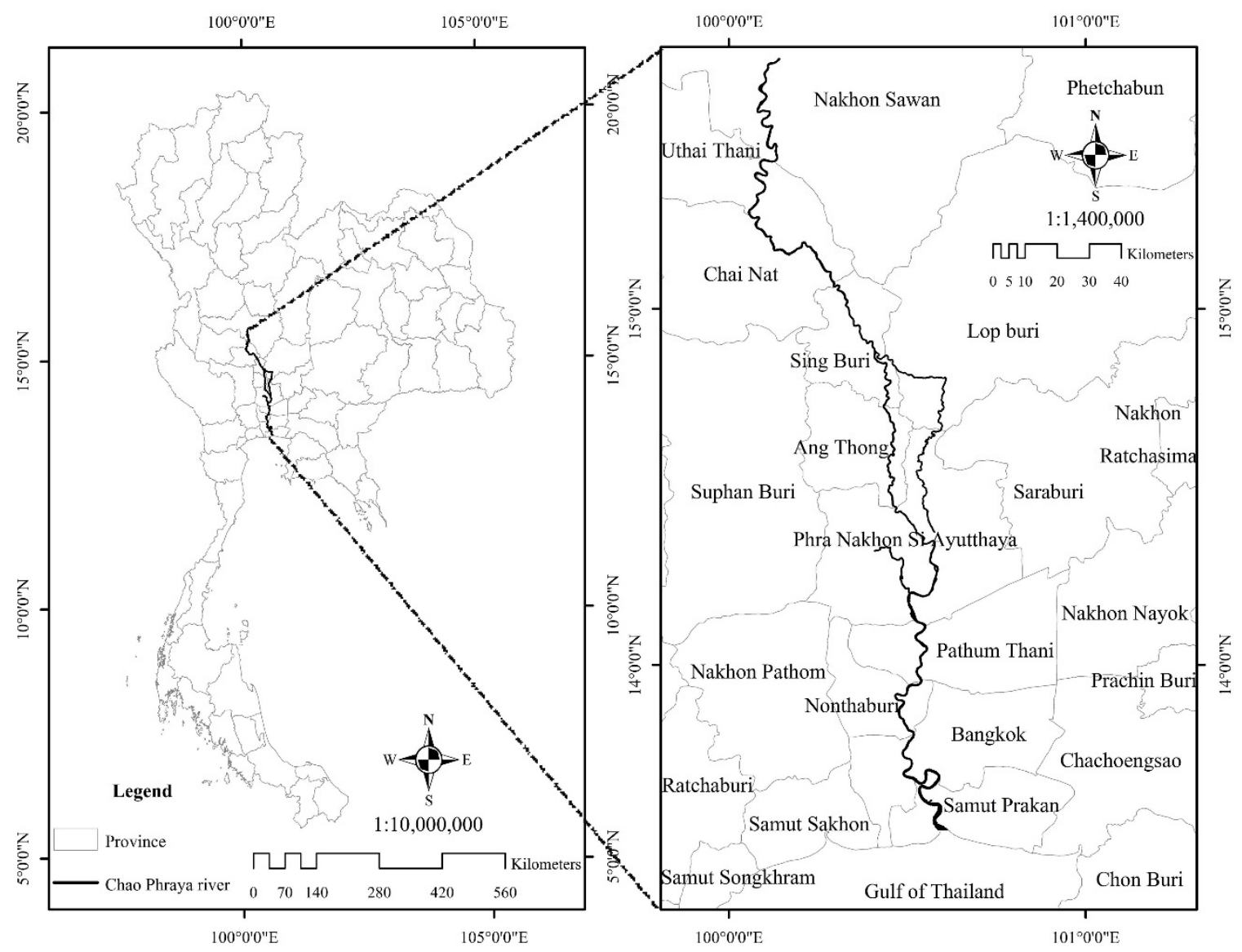

Figure 1. Chao Phraya River is $372 \mathrm{~km}$ long and passes through 11 cities in central Thailand.

\subsection{Collection of Large Tree Data}

Fieldwork was conducted monthly from May 2017 to July 2018. Large trees were selected based on the following criteria [33]: trunk diameter at $1.3 \mathrm{~m}$ height $\geq 100 \mathrm{~cm}$; distinctive tree form; important species; and/or cultural, historical, commemorative, or ecological significance. All large trees assessed were situated along the Chao Phraya River Rim, within $50 \mathrm{~m}$ of both the left and right river banks and within the area regulated by the Marine Department of the Ministry of Transport of Thailand [34]. The location and dimensions of the sampled trees were noted during the field surveys. Each tree was evaluated for diameter at breast height (DBH), total height, and average canopy cover (ACC). DBH $(\mathrm{cm})$ and total height $(\mathrm{m})$ were measured using diameter tape and a laser rangefinder (Nikon Forestry Pro II), respectively. The average canopy cover $(\mathrm{m})$ was given by the average of the canopy range distance from north-south $(\mathrm{N}-\mathrm{S})$ and east-west $(\mathrm{E}-\mathrm{W})$ $[(\mathrm{N}-\mathrm{S}+\mathrm{E}-\mathrm{W}) / 2]$; distances were measured using measuring tape. We identified tree species by comparing leaf specimens with standard specimens [35] at the Department of National Parks, Wildlife, and Plant Conservation. The plant names used in this study follow the Flora of Thailand [36]. 


\subsection{Data Analyses}

In the analysis, we pooled the data from Uthai Thani (UT) with those of nearby Nakhon Sawan (NS), while data from Samut Prakan (SP) were pooled with nearby Bangkok (BK). The data were pooled because UT and SP had very small datasets. Therefore, the data analysis included a total of nine study sites: Nakhon Sawan (NS, i.e., NS + UT), Chai Nat $(\mathrm{CN})$, Sing Buri (SB), Lop Buri (LP), Ang Thong (AT), Ayutthaya (AY), Pratum Thani (PT), Nonthaburi (NT), and Bangkok (BK, i.e., BK + SP).

Species were classified into the following frequency classes [33]: dominant $(>100$ trees per species), common (10-100 trees per species), rare (2-9 trees per species) and solitary (one tree per species). For each site, we analyzed the species diversity, evenness, and importance value (IV). The Shannon-Wiener index $\left(H^{\prime}\right)$ was calculated as $-\sum p i^{*}(\ln p i)$, where $p i$ is the number of species $i$ divided by the total number of all species [37]. The Pielou evenness index $(J)$ was calculated as $H^{\prime} / \ln S$, where $S$ is the total number of species [38]. The IV was calculated as the sum of relative abundance (RA) and relative dominance (RD) $[33,39]$. The RA of a given species was calculated as the species number divided by the total number of all species, multiplied by 100 . The RD of a given species was calculated as the basal area at breast height divided by the total basal area at breast height of all species, multiplied by 100 .

We used detrended correspondence analysis (DCA) ordination to determine similarity in species composition of large trees across the study sites [40]. DCA is an indirect gradient analysis technique that detects gradients in species composition using species abundance data [41]. The tree species matrix contained tree abundance data based on the IV of each species in each site. The results of DCA ordination are presented with species or plot within two axes, where each axis corresponds to a dimension in space [42]. Data were analyzed using PC-ORD for Windows (ver. 6; MjM Software, Gleneden Beach, OR, USA).

\section{Results and Discussion}

\subsection{Species Composition of Large Trees}

A total of 987 large trees were found in the study area, including 65 species from 48 genera and 31 families, of which 44 species were evergreen and 21 were deciduous (Table 1). Overall, species diversity was lower, but individual stem number was higher, compared to old valuable trees in Hong Kong [33]. The frequency classes indicated two dominant species, Dipterocarpus alatus and Hopea odorata, together accounting for $59.07 \%$ of the total RA. Dipterocarpus alatus had the highest number of individuals (430 trees) and accounted for the highest proportion of RA (43.57\%). Eight common species ( $>10$ trees) were identified, Ficus religiosa, Crudia chrysantha, Diospyros decandra, Mimusops elengi, Terminalia bellirica, Diospyros castanea, Syzygium cumini, and Pterocarpus macrocarpus, together accounting for $28.47 \%$ of the RA. Fifty-five species had less than 10 trees each, indicating a large bias toward rare $(n=28)$ and solitary $(n=27)$ species. Each of these 55 species fell below the average RA of $0.23 \%$ per species (Table 1 ). The top two species, D. alatus and F. religiosa, together accounted for approximately $50 \%$ of the RD, at $35.22 \%$ and $14.80 \%$, respectively, while the remaining 66 species accounted for $17 \%$ of the RD (Table 1). Nine species, including H. odorata, C. chrysantha, and Ficus microcarpa, had RD values between $>1$ and $<10 \%$. The 55 species with RD less than $1 \%$ all fell below the average of $0.23 \%$. The top four species (IV > 10\%) were D. alatus, H. odorata, F. religiosa, and C. chrysantha, with IVs of $78.79 \%, 25.01 \%, 21.69 \%$, and $16.12 \%$, respectively. Thirteen species had IVs of $1-10 \%$, and the remaining 48 species had values less than $1 \%$. Evergreen species were more abundant than deciduous species, similar to the largest trees in Bangkok Metropolitan Authority [30]. Evergreens may have been more abundant because the study region is covered by floodplain forest, which likely included evergreen communities with various key aquatic-terrestrial ecosystem functions [43]. Ficus religiosa and Samanea saman have been reported as dominant species among the largest trees in Bangkok Metropolitan Authority [30]. However, we excluded Samanea saman from the present study, as it is an exotic species native to tropical America [44]. 
Table 1. Species list of large trees along the Chao Phraya River Rim ranked by importance value (IV), along with information on leaf duration (LD; D, deciduous; E, evergreen; NS, number of stems; BA, basal area), frequency class (FC; D, dominant; $C$, common; $R$, rare; $S$, solitary), relative abundance (RA), and relative dominance (RD).

\begin{tabular}{|c|c|c|c|c|c|c|c|c|}
\hline Species & Code & LD & NS & BA & FC & RA & RD & IV \\
\hline Dipterocarpus alatus & DIPALA & $\mathrm{D}$ & 430 & 596.37 & $\mathrm{D}$ & 43.57 & 35.22 & 78.79 \\
\hline Hopea odorata & HOPOD & $\mathrm{E}$ & 153 & 160.99 & $\mathrm{D}$ & 15.50 & 9.51 & 25.01 \\
\hline Ficus religiosa & FICRE & $\mathrm{E}$ & 68 & 220.92 & $\mathrm{C}$ & 6.89 & 14.80 & 21.69 \\
\hline Crudia chrysantha & CRUCH & $\mathrm{D}$ & 78 & 139.13 & $\mathrm{C}$ & 7.90 & 8.22 & 16.12 \\
\hline Diospyros decandra & DIODE & $\mathrm{E}$ & 42 & 38.04 & $\mathrm{C}$ & 4.26 & 2.25 & 6.50 \\
\hline Mimusops elengi & MIMEL & $\mathrm{E}$ & 30 & 22.68 & $\mathrm{C}$ & 3.04 & 1.34 & 4.38 \\
\hline Ficus microcarpa & FICMI & $\mathrm{E}$ & 6 & 44.72 & $\mathrm{R}$ & 0.61 & 2.64 & 3.25 \\
\hline Terminalia bellirica & TERBE & $\mathrm{D}$ & 19 & 21.70 & $\mathrm{C}$ & 1.93 & 1.28 & 3.21 \\
\hline Diospyros castanea & DIOCA & $\mathrm{E}$ & 18 & 15.88 & $\mathrm{C}$ & 1.82 & 0.94 & 2.76 \\
\hline Syzygium cumini & SYZCU & $\mathrm{E}$ & 15 & 19.28 & $\mathrm{C}$ & 1.52 & 1.14 & 2.66 \\
\hline Ficus concinna & FICCO & $\mathrm{E}$ & 7 & 32.43 & $\mathrm{R}$ & 0.71 & 1.92 & 2.62 \\
\hline Ficus altissima & FICAL & $\mathrm{E}$ & 2 & 28.37 & $\mathrm{R}$ & 0.20 & 1.68 & 1.88 \\
\hline Sterculia foetida & STEFO & $\mathrm{D}$ & 8 & 13.88 & $\mathrm{R}$ & 0.81 & 0.82 & 1.63 \\
\hline Pterocarpus macrocarpus & PTEMA & $\mathrm{D}$ & 11 & 8.06 & $\mathrm{C}$ & 1.11 & 0.48 & 1.59 \\
\hline Ficus drupacea & FICDR & $\mathrm{E}$ & 3 & 15.89 & $\mathrm{R}$ & 0.30 & 0.94 & 1.24 \\
\hline Shorea roxburghii & SHORO & $\mathrm{D}$ & 7 & 5.40 & $\mathrm{R}$ & 0.71 & 0.32 & 1.03 \\
\hline Bombax ceiba & BOMCE & $\mathrm{D}$ & 5 & 8.46 & $\mathrm{R}$ & 0.51 & 0.50 & 1.01 \\
\hline Saraca thaipingensis & SARTH & $\mathrm{E}$ & 7 & 4.48 & $\mathrm{R}$ & 0.71 & 0.26 & 0.97 \\
\hline Mangifera caloneura & MANCA & $\mathrm{E}$ & 7 & 3.76 & $\mathrm{R}$ & 0.71 & 0.22 & 0.93 \\
\hline Ficus insignis & FICIN & $\mathrm{E}$ & 1 & 12.26 & $\mathrm{~S}$ & 0.10 & 0.72 & 0.83 \\
\hline Ficus rumphiin & FICRU & $\mathrm{E}$ & 3 & 7.15 & $\mathrm{R}$ & 0.30 & 0.42 & 0.73 \\
\hline Ficus benjamina & FICBE & $\mathrm{E}$ & 2 & 8.10 & $\mathrm{R}$ & 0.20 & 0.48 & 0.68 \\
\hline Hydnocarpus castanea & HYDCA & $\mathrm{E}$ & 5 & 2.70 & $\mathrm{R}$ & 0.51 & 0.16 & 0.67 \\
\hline Pterocarpus indicus & PTEIN & $\mathrm{D}$ & 2 & 7.78 & $\mathrm{R}$ & 0.20 & 0.46 & 0.66 \\
\hline Bombax anceps & BOMAN & $\mathrm{D}$ & 2 & 5.65 & $\mathrm{R}$ & 0.20 & 0.33 & 0.54 \\
\hline Xanthophyllum lanceatum & XANLA & $\mathrm{E}$ & 3 & 3.68 & $\mathrm{R}$ & 0.30 & 0.22 & 0.52 \\
\hline Ficus racemosa & FICRA & $\mathrm{E}$ & 1 & 6.25 & $\mathrm{~S}$ & 0.10 & 0.37 & 0.47 \\
\hline Nauclea orientalis & NAUOR & $\mathrm{D}$ & 2 & 4.38 & $\mathrm{R}$ & 0.20 & 0.26 & 0.46 \\
\hline Schleichera oleosa & SCHOL & $\mathrm{D}$ & 3 & 2.08 & $\mathrm{R}$ & 0.30 & 0.12 & 0.43 \\
\hline Maerua siamensis & MAESI & $\mathrm{E}$ & 2 & 2.14 & $\mathrm{R}$ & 0.20 & 0.13 & 0.33 \\
\hline Manilkara hexandra & MANHE & $\mathrm{E}$ & 2 & 1.80 & $\mathrm{R}$ & 0.20 & 0.11 & 0.31 \\
\hline Diospyros mollis & DIOMO & $\mathrm{D}$ & 2 & 1.70 & $\mathrm{R}$ & 0.20 & 0.10 & 0.30 \\
\hline Beilschmiedia roxburghiana & BEIRO & $\mathrm{D}$ & 2 & 1.60 & $\mathrm{R}$ & 0.20 & 0.09 & 0.30 \\
\hline Dalbergia nigrescens & DALNI & $\mathrm{D}$ & 2 & 1.35 & $\mathrm{R}$ & 0.20 & 0.08 & 0.28 \\
\hline Aphanamixis polystachya & APHPO & $\mathrm{E}$ & 2 & 1.19 & $\mathrm{R}$ & 0.20 & 0.07 & 0.27 \\
\hline Mammea siamensis & MAMSI & $\mathrm{E}$ & 2 & 1.00 & $\mathrm{R}$ & 0.20 & 0.06 & 0.26 \\
\hline Calophyllum inophyllum & CALIN & $\mathrm{E}$ & 2 & 0.73 & $\mathrm{R}$ & 0.20 & 0.04 & 0.25 \\
\hline Terminalia chebula & TERCH & $\mathrm{D}$ & 2 & 0.71 & $\mathrm{R}$ & 0.20 & 0.04 & 0.24 \\
\hline Bauhinia malabarica & BAUMA & $\mathrm{D}$ & 1 & 2.31 & $\mathrm{~S}$ & 0.10 & 0.14 & 0.24 \\
\hline Putranliva roxburghii & PUTRO & $\mathrm{E}$ & 2 & 0.56 & $\mathrm{R}$ & 0.20 & 0.03 & 0.24 \\
\hline Alstonia scholaris & ALSSC & $\mathrm{E}$ & 1 & 2.27 & S & 0.10 & 0.13 & 0.24 \\
\hline Strychnos nux-blanda & STRNU & $\mathrm{D}$ & 1 & 2.14 & $S$ & 0.10 & 0.13 & 0.23 \\
\hline Terminalia citrina & TERCI & $\mathrm{E}$ & 2 & 0.38 & $\mathrm{R}$ & 0.20 & 0.02 & 0.22 \\
\hline Pterospermum diversifolium & PTEDI & $\mathrm{D}$ & 1 & 1.53 & $\mathrm{~S}$ & 0.10 & 0.09 & 0.19 \\
\hline Erythrina fusca & ERYFU & $\mathrm{E}$ & 1 & 1.51 & $\mathrm{~S}$ & 0.10 & 0.09 & 0.19 \\
\hline Adenanthera pavonina & ADEPA & $\mathrm{E}$ & 1 & 0.95 & $\mathrm{~S}$ & 0.10 & 0.06 & 0.16 \\
\hline Persea kurzii & PERKU & $\mathrm{E}$ & 1 & 0.77 & $S$ & 0.10 & 0.05 & 0.15 \\
\hline Diospyros rhodocalyx & DIORH & $\mathrm{E}$ & 1 & 0.76 & $\mathrm{~S}$ & 0.10 & 0.05 & 0.15 \\
\hline Alangium salviifolium & ALASA & $\mathrm{E}$ & 1 & 0.68 & $\mathrm{~S}$ & 0.10 & 0.04 & 0.14 \\
\hline Amherstia nobilis & AMHNO & $\mathrm{E}$ & 1 & 0.62 & $\mathrm{~S}$ & 0.10 & 0.04 & 0.14 \\
\hline Dillenia indica & DILIN & $\mathrm{E}$ & 1 & 0.59 & $S$ & 0.10 & 0.03 & 0.14 \\
\hline Vatica diospyroides & VATDI & $\mathrm{E}$ & 1 & 0.57 & $S$ & 0.10 & 0.03 & 0.13 \\
\hline Madhuca pierrei & MADPI & $\mathrm{E}$ & 1 & 0.56 & $S$ & 0.10 & 0.03 & 0.13 \\
\hline Mesua ferrea & MESFE & $\mathrm{E}$ & 1 & 0.53 & $S$ & 0.10 & 0.03 & 0.13 \\
\hline Afzelia xylocarpa & AFZXY & $\mathrm{D}$ & 1 & 0.48 & $\mathrm{~S}$ & 0.10 & 0.03 & 0.13 \\
\hline
\end{tabular}


Table 1. Cont.

\begin{tabular}{ccccccccc}
\hline Species & Code & LD & NS & BA & FC & RA & RD & IV \\
\hline Sindora siamensis & SINSI & D & 1 & 0.43 & S & 0.10 & 0.03 & 0.13 \\
Manilkara kauki & MANKA & E & 1 & 0.41 & S & 0.10 & 0.02 & 0.13 \\
Suregada multiflora & SURMU & E & 1 & 0.37 & S & 0.10 & 0.02 & 0.12 \\
Casearia grewiifolia & CASGR & E & 1 & 0.37 & S & 0.10 & 0.02 & 0.12 \\
Phyllocarpus septentrionalis & PHYSE & E & 1 & 0.35 & S & 0.10 & 0.02 & 0.12 \\
Mangifera indica & MANIN & E & 1 & 0.32 & S & 0.10 & 0.02 & 0.12 \\
Carallia brachiata & CARBR & E & 1 & 0.31 & S & 0.10 & 0.02 & 0.12 \\
Barringtonia asiatica & BARAS & E & 1 & 0.25 & S & 0.10 & 0.01 & 0.12 \\
Vitex glabrata & VITGL & D & 1 & 0.22 & S & 0.10 & 0.01 \\
Parkia timoriana & PARTI & E & 1 & 0.22 & S & 0.10 & 0.01 & 0.11 \\
\hline Total & & & 987 & 1693.12 & & 100 & 100 & 200 \\
Average & & & & & & 1.54 & 1.54 & 3.08 \\
\hline
\end{tabular}

Based on the frequency classes and IV ranking, both of the dominant species (D. alatus and $H$. odorata) are well-known species of large trees in the Chao Phraya River Rim. Moreover, both species are dipterocarps (Dipterocarpaceae) that dominate the floodplain forests along the Chao Phraya River [14]. The distribution of these two species is determined by precipitation $[45,46]$, as they are often dominant in tropical forests in Southeast Asia where high rainfall is a limiting factor [47]. Historically, both species were severely reduced by urbanization and were once only found in small forest patches and as isolated individuals along the Chao Phraya River [14]. In response, the Thai government announced that these two species would be protected by forest laws [48], which is likely why they now dominate the study area.

Two common species, F. religiosa and C. chrysantha, exhibited IVs higher than $10 \%$, suggesting their importance in the study area. Ficus religiosa is a large, asymmetrical evergreen tree, reaching $20 \mathrm{~m}$ in height, with a DBH of $1.5-2 \mathrm{~m}$, broad branches, and a trunk characterized by low buttresses [49]. This species is important in Buddhism, as it is associated with the enlightenment of the Lord Buddha [50]. Therefore, many individuals of this species have been planted at Buddhist temples, and it adds spiritual value to nearby communities [51]. Isolated individuals of $C$. chrysantha were also scattered throughout governmental and temple areas at the study sites. This species has a large buttress and large spreading branches, which provide shade [52]. Along with H. odorata, C. chrysantha was an important species within floodplain forests of riparian areas of the Chao Phraya River [14]. In addition, Vatica diospyroides is included on the Thailand Red List as a critically endangered and rare species [53]. In this study, V. diospyroides was classified as solitary (i.e., only one stem was found), suggesting that its status is very critical, such that urgent preservation efforts are required in the study area. In general, urbanization has been a major cause of native species extinctions, and endangered and rare species are the most at risk [54]. We also found many solitary individuals of large tree species that are rare in the urbanizing areas along the Chao Phraya River Rim, although they are common in natural forests. This finding indicates that urbanization has substantially reduced the populations of certain forest tree species. The complex nature of urban land use can have complicated effects on local biodiversity loss [55].

\subsection{Species Diversity by City}

The distribution of large trees was highly uneven among the nine study sites (Table 2). Ayutthaya had the highest number of species (30 species), followed by metropolitan Bangkok (27) and Sing Buri (21), while all other cities had fewer than 20 species. In cities such Sing Buri, which are situated along the upper reaches of rivers, large trees were mainly found in municipal or suburban areas, whereas in cities such Ayutthaya and Bangkok, along the lower reaches of rivers, large trees were mainly in urban areas. Sing Buri contained the most individual large trees (258 trees), followed by Ayutthaya (222); all 
other cities had less than 100 trees. A different pattern for mean tree height was observed across cities. Metropolitan Bangkok exhibited the shortest mean tree height (14.52 m); the other cities all had values higher than $20 \mathrm{~m}$. The total basal area of trees in Sing Buri was highest, at $474.25 \mathrm{~m}^{2} \mathrm{ha}^{-1}$, followed by Ayutthaya $\left(358.17 \mathrm{~m}^{2} \mathrm{ha}^{-1}\right)$ and Chai Nat $\left(232.35 \mathrm{~m}^{2} \mathrm{ha}^{-1}\right)$. Total basal area was lowest in Nakhon Sawan. Crown cover spread was widest in Ayutthaya, followed by Sing Buri and Bangkok. The Shannon-Wiener index of species diversity was greater than 2 for four cities: Bangkok (2.64), Chai Nat (2.27), Ayutthaya (2.24), and Nakhon Sawan (2.12). In contrast, values were lower than 2 in Lop Buri, Sing Buri, Ang Thong, Prathum Thani, and Nonthaburi. J was highest in Nonthaburi (0.82), Bangkok (0.80), and Nakhon Sawan (0.80), and lowest in Sing Buri (Table 2).

Table 2. Frequency, dimensions, and diversity of large trees. Data include the number of species (No. Sp.), number of stems (No. S), mean tree height (MHt, m), basal area (BA, $\mathrm{m}^{2}$ ), average canopy cover $\left(\mathrm{ACC}, \mathrm{m}^{2}\right)$, Shannon-Wiener index $\left(H^{\prime}\right)$, and evenness index $(J)$ for nine cities along the Chao Phraya River Rim: Nakhon Sawan (NS), Chai Nat (CN), Sing Buri (SB), Lop Buri (LP), Ang Thong (AT), Ayutthaya (AY), Pratum Thani (PT), Nonthaburi (NT), and Bangkok (BK).

\begin{tabular}{cccccccc}
\hline Province & No. Sp. & No. $\mathbf{S}$ & MHt & BA & ACC & $\boldsymbol{H}^{\prime}$ & $\boldsymbol{J}$ \\
\hline NS & 14 & 47 & 23.02 & 67.64 & 6992.96 & 2.12 & 0.80 \\
CN & 19 & 99 & 22.99 & 232.35 & $14,283.11$ & 2.27 & 0.77 \\
LP & 14 & 74 & 29.62 & 121.47 & $16,359.80$ & 1.79 & 0.68 \\
SB & 21 & 258 & 29.21 & 474.25 & $40,064.33$ & 1.30 & 0.43 \\
AT & 12 & 97 & 27.22 & 133.42 & $39,137.90$ & 1.28 & 0.51 \\
AY & 30 & 222 & 26.66 & 358.17 & $64,339.10$ & 2.24 & 0.66 \\
PT & 14 & 54 & 23.67 & 77.98 & $13,662.54$ & 1.97 & 0.75 \\
NT & 11 & 46 & 21.13 & 77.05 & $12,344.55$ & 1.96 & 0.82 \\
BK & 27 & 90 & 14.52 & 150.77 & $29,947.30$ & 2.64 & 0.80 \\
Total & 65 & 987 & 218.04 & 1693.12 & $237,131.59$ & 17.56 & 6.21 \\
Average & 18 & 110 & 24.23 & 188.12 & $26,347.95$ & 1.95 & 0.69 \\
\hline
\end{tabular}

These results suggest that the cities along the upper part of the Chao Phraya River have more individual trees than those along the lower part, likely because the former cities are primarily rural and have only small urban areas. The lifestyle of the Thai people in rural areas often requires large trees for shading, and they are typically considered sacred, which discourages their destruction [56]. The rural city of Sing Buri had the largest basal area of large trees. Furthermore, the rural cities along the upper part of the river have abandoned areas in which small forest patches remain; these areas were dominated by the largest individuals of Dipterocarpus alatus [14]. Ayutthaya had the highest species and crown cover, mostly attributable to Buddhist temples and ancient monuments. The ancient Thai culture believed that large trees preserved in temples or palaces were sacred [57]. Historic Ayutthaya is an ancient city that was the capital of Thailand (formerly known as Siam) for 417 years; it contains many temples and ancient sites and was declared a Cultural World Heritage Site in 1991. Some large trees may have been preserved since the Ayutthaya period, such as F. religiosa, which is important to Buddhist beliefs [50]. However, no studies have definitively determined the ages of these large trees.

Bangkok contains a high diversity of large tree species, most of which occur in Buddhist temples, similar to Ayutthaya. Bangkok has many large temples along the Chao Phraya River Rim, and these sites tend to have large trees to ensure the seclusion preferred by Buddhist temples [57]. Several of the large trees in Bangkok are already registered as heritage trees, particularly the exceptionally large Ficus species found on Buddhist temple grounds; large trees also occur in the green spaces scattered throughout Bangkok [30]. Green spaces with large trees in urbanized areas provide environmental benefits, enhance social well-being, and increase welfare levels $[16,51,58]$. Large trees are also important components of sensory gardens for recreational development $[59,60]$.

Tree height was lowest in Bangkok, which is a dense metropolitan city with many tall buildings. In rapidly urbanizing areas, it is often difficult to protect urban trees in the 
face of development pressure [17]. Therefore, large trees require trimming and pruning to limit height and branch size, to avoid damaging the property of those who live nearby through uprooting or falling dry branches [61,62]. Pruning also provides a strong branch structure that can limit injury from hazardous trees. Cities that are appropriately structured to accommodate trees benefit from an aesthetic visual style that ultimately helps improve human health [62].

\subsection{Unique Species}

The DCA ordination produced relatively high eigenvalues of 0.56 (axis 1) and 0.32 (axis 2), indicating substantial species turnover along the gradients represented by the first two axes [41]. The DCA revealed unique species at each of the nine sites (Figure 2). Dominant species, such as Dipterocarpus alatus and Hopea odorata, were found in all cities, particularly in Lop Buri and Prathum Thani, respectively. A previous study reported that the upper and lower parts of the Chao Phraya River are suitable environments for populations of Dipterocarpus alatus and Hopea odorata, respectively [45,46]. The key limiting factors for these two species are distance from the sea, urbanized areas, and rainfall [14]. The four most common species, Ficus religiosa, Crudia chrysantha, Diospyros decandra, and Mimusops elengi, were found in over half of the cities, particularly in those along the lower part of the Chao Phraya River. All dominant and common species exhibited high abundance and occurred in many urban areas; thus, their status is not yet critical. Many trees of the dominant and common species were located in temples and parks, indicating that they have been preserved in areas insulated against the negative effects of urbanization $[30,63]$.

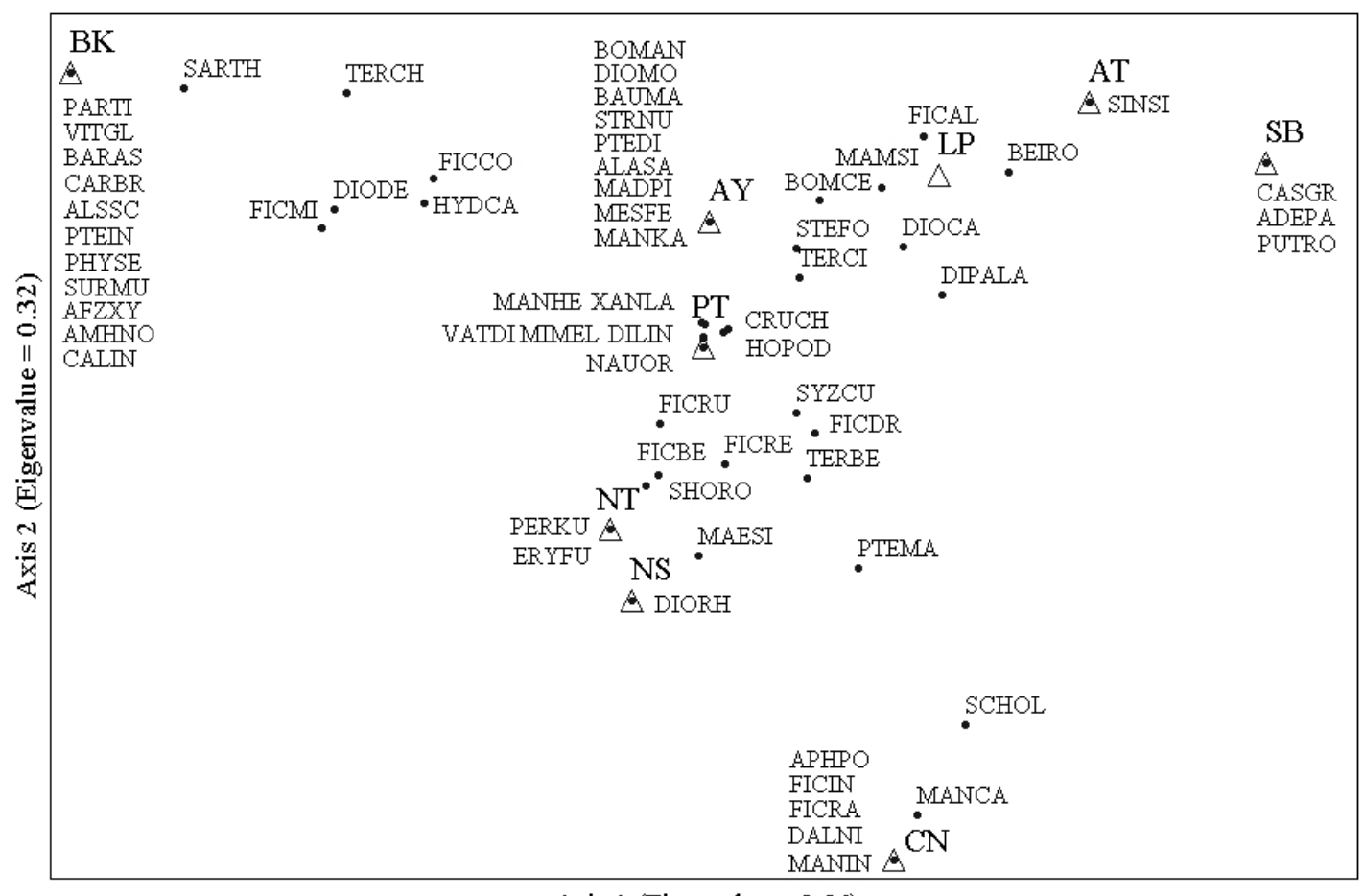

Axis 1 (Eigenvalue $=0.56)$

Figure 2. The first two axes of the DCA ordination for large tree species in nine provinces along the Chao Phraya River Rim. Provinces are represented by triangles and tree species as black dots. See Tables 1 and 2 for the species and province abbreviations, respectively.

The number of unique species was highest (11 species) in Bangkok, followed by Ayutthaya and Chai Nat (nine and five species, respectively). The cities of Prathum Thani, Nonthaburi, Nakhon Sawan, Sing Buri, and Ang Thong contained one to three unique species, and only Lop Buri lacked any unique species (Figure 2). These findings suggest that the number of unique species is higher in large, rapidly urbanizing cities, 
such as Bangkok and Ayutthaya, compared to rural cities. All of the unique species in the study area were classified as rare or solitary (i.e., one to two trees), yet they are all common within natural forests [64]. Unique species, such as Parkia timoriana, Vitex glabrata, Carallia brachiata, Alstonia scholaris, Pterocarpus indicus, Afzelia xylocarpa, Diospyros mollis, Pterospermum diversifolium, and Madhuca pierrei, have been classified as restricted timber species by the Royal Forest Department [48]; all of these species can be found in Bangkok and Ayutthaya. These results suggest that largescale and rapid urbanization can reduce populations of large trees, especially protected species. These large trees species could easily disappear from sites along the Chao Phraya River Rim. The necessity for urban and economic growth has superseded concerns regarding green and livable cities $[65,66]$, and there are now severe shortages of developable land [33]. Continuous expansion of the human population and urbanized land, which is associated with intensive anthropogenic disturbances, could threaten the health and quality of urban trees [3]. Many urban trees in crowded cities suffer from stressful microclimates, poor soil conditions, and root stress [67], which can lead to premature mortality.

\subsection{Implications for Management}

A high diversity of urban tree species increases their adaptability, survival potential, functionality, and robustness against environmental changes [13]. However, the relationship between urbanization and urban tree abundance varies among landscapes [68]. The present study documented 987 individuals of 65 species of large trees along the Chao Phraya River Rim. The large trees at the study sites were comprised of a few dominant species, such as Dipterocarpus alatus and Hopea odorata, but most trees belonged to rare species. Several of these rare species are primarily found in large, rapidly urbanizing cities such as Ayutthaya and metropolitan Bangkok. This indicates that rapid urbanization can reduce populations and jeopardize the existence of large tree species. Such trees are invaluable assets of cities but are often in conflict with urban structures, especially in rapidly urbanizing areas. In general, large cities provide poor conditions for urban trees [18]; to arrest their continual decline and enhance long-term conservation, urban planners require an in-depth understanding of urban tree management.

Heritage tree registration is necessary, especially in large, rapidly urbanizing areas such Ayutthaya and metropolitan Bangkok. Distinctive trees tend to be preserved in the older neighborhoods of ancient cities [69]. Generally, heritage registration focuses on large trees with cultural significance [17]. For example, since 2018, the "Trees of Siam: Treasures of the Land under the Royal Benevolence of His Majesty the King" event has been held in Thailand. This focuses on heritage trees characterized by large size, distinctive forms, and cultural or historical significance [28]. This event has encouraged citizens to pay more attention to the conservation of large trees. The largest individual of Samanea saman was part of the Trees of Siam event in Kanchanaburi; it attracted a large number of tourists, thus improving the local economy. Monitoring and maintenance are also crucial for preserving large urban trees, particularly the oldest ones that can easily be damaged by disease, insects, natural disasters, and human conflicts [18]. Since 2004, the Hong Kong Government has registered about 500 heritage trees in developed areas and rural tourist spots, which are subject to continuous monitoring e.g., [22,33,39]. Surveys and risk assessments of large trees in rapidly urbanizing areas should also be carried out. Moreover, maintenance of large trees is needed, where neglecting damage can lead to mortality [70]. Educating urban communities about the importance of large trees can help to reduce conflict between humans and trees. Finally, urban environmental policy makers should focus on the regulating function of forests when designing and managing urban forests [71]. Strengthening preservation policies for large trees in rapidly urbanizing areas along the Chao Phraya River Rim could facilitate sustainable management. 


\section{Conclusions}

In this study, we surveyed 987 large trees belonging to 65 species, 48 genera, and 31 families. Dipterocarpus alatus and Hopea odorata are the dominant tree species in our study sites along the Chao Phraya River. Cities located along the upper part of the river contained many large trees, especially Sing Buri. The cities located along the lower part of the river are characterized by rapid urbanization and exhibited the highest diversity of large tree species, including many unique species. These findings suggest that large, rapidly urbanizing cities harbor high species diversity but relatively small populations of large trees. Thus, management planning for the preservation of large trees is urgently needed in areas of rapid urbanization. We recommend that large heritage trees be registered, especially in major, rapidly urbanizing areas such as Ayutthaya and Bangkok, to increase interest in large tree conservation and awareness of the importance thereof. Future studies should assess the benefits and ecosystem services provided by these large trees, as well as the risks to their continued presence, so that they may be appreciated by the Thai people for many generations to come.

Author Contributions: All authors significantly contributed to this paper. Conceptualization, L.A.; methodology, L.A., T.K., M.N., and T.Y.; investigation, S.N.; analysis, L.A. and T.K.; writing—original draft preparation, L.A.; writing-review and editing, L.A.; supervision, L.A. and S.N. All authors have read and agreed to the published version of the manuscript.

Funding: This research was a part of the project titled 'Ecology of big tree for conservation in low land of Chao Phraya River', funded by the PTT Reforestation and Ecosystem Institute, PTT Public Company Limited.

Institutional Review Board Statement: Not applicable.

Informed Consent Statement: Not applicable.

Data Availability Statement: Restrictions apply to the availability of these data. Data are available with the permission of the PTT Reforestation and Ecosystem Institute, PTT Public Company Limited.

Acknowledgments: This research would not have been possible without the assistance of students from the Department of Agroforestry, Phrae Campus, Maejo University. We are also indebted to the PTT Reforestation and Ecosystem Institute, PTT Public Company Limited.

Conflicts of Interest: The authors declare no conflict of interest.

\section{References}

1. Livesley, S.J.; Escobedo, F.J.; Morgenroth, J. The Biodiversity of Urban and Peri-Urban Forests and the Diverse Ecosystem Services They Provide as Socio-Ecological Systems. Forest 2016, 7, 291. [CrossRef]

2. Lepczyk, C.A.; Aronson, M.F.J.; Evans, K.L.; Goddard, M.; Lerman, S.B.; MacIvor, J.S. Biodiversity in the City: Fundamental Questions for Understanding the Ecology of Urban Green Spaces for Biodiversity Conservation. Bioscience 2017, 67, 799-807. [CrossRef]

3. Tubby, K.V.; Webber, J.F. Pests and diseases threatening urban trees under a changing climate. Forestry 2010, 83, 451-459. [CrossRef]

4. Cruz-Sandoval, M.; Ortego, M.I.; Roca, E. Tree Ecosystem Services, for Everyone? A Compositional Analysis Approach to Assess the Distribution of Urban Trees as an Indicator of Environmental Justice. Sustainability 2020, 12, 1215. [CrossRef]

5. Chiesura, A. The role of urban parks for the sustainable city. Landsc. Urban Plan. 2004, 68, 129-138. [CrossRef]

6. Turner-Skoff, J.B.; Cavender, N. The benefits of trees for livable and sustainable communities. Plants People Planet 2019, 1, 323-335. [CrossRef]

7. Pataki, D.E.; Alberti, M.; Cadenasso, M.L.; Felson, A.J.; McDonnell, M.J.; Pincetl, S.; Pouyat, R.V.; Setälä, H.; Whitlow, T.H. The Benefits and Limits of Urban Tree Planting for Environmental and Human Health. Front. Ecol. Evol. 2021, 9, 603757. [CrossRef]

8. Ballinas, M.; Barradas, V.L. The Urban Tree as a Tool to Mitigate the Urban Heat Island in Mexico City: A Simple Phenomenological Model. J. Environ. Qual. 2016, 45, 157-166. [CrossRef] [PubMed]

9. Nowak, D.J.; Crane, D.E.; Stevens, J.C. Air pollution removal by urban trees and shrubs in the United States. Urban For. Urban Green. 2006, 4, 115-123. [CrossRef]

10. Akbari, H. Shade trees reduce building energy use and CO2 emissions from power plants. Environ. Pollut. 2002, 116 (Suppl. 1), S119-S126. [CrossRef] 
11. Wolf, K.L.; Lam, S.T.; McKeen, J.K.; Richardson, G.R.; Bosch, M.V.D.; Bardekjian, A.C. Urban Trees and Human Health: A Scoping Review. Int. J. Environ. Res. Public Health 2020, 17, 4371. [CrossRef] [PubMed]

12. Bonilla-Duarte, S.; Gómez-Valenzuela, V.; Vargas-de la Mora, A.-L.; García-García, A. Urban Forest Sustainability in Residential Areas in the City of Santo Domingo. Forests 2021, 12, 884. [CrossRef]

13. Nock, C.A.; Paquette, A.; Follett, M.; Nowak, D.J.; Messier, C. Effects of Urbanization on Tree Species Functional Diversity in Eastern North America. Ecosystems 2013, 16, 1487-1497. [CrossRef]

14. Asanok, L.; Kamyo, T.; Norsaengsri, M.; Salinla-Um, P.; Rodrungruang, K.; Karnasuta, N.; Navakam, S.; Pattanakiat, S.; Marod D.; Duengkae, P.; et al. Vegetation community and factors that affect the woody species composition of riparian forests growing in an urbanizing landscape along the Chao Phraya River, central Thailand. Urban For. Urban Green. 2017, 28, 138-149. [CrossRef]

15. Melliger, R.L.; Braschler, B.; Rusterholz, H.-P.; Baur, B. Diverse effects of degree of urbanisation and forest size on species richness and functional diversity of plants, and ground surface-active ants and spiders. PLoS ONE 2018, 13, e0199245. [CrossRef]

16. Bai, X.; McPhearson, T.; Cleugh, H.; Nagendra, H.; Tong, X.; Zhu, T.; Zhu, Y.-G. Linking Urbanization and the Environment: Conceptual and Empirical Advances. Annu. Rev. Environ. Resour. 2017, 42, 215-240. [CrossRef]

17. Jim, C.Y. Urban Heritage Trees: Natural-Cultural Significance Informing Management and Conservation. In E-Democracy for Smart Cities; Springer: Berlin/Heidelberg, Germany, 2017; pp. 279-305.

18. Jim, C.; Zhang, H. Defect-disorder and risk assessment of heritage trees in urban Hong Kong. Urban For. Urban Green. 2013, 12, 585-596. [CrossRef]

19. Wen, L.; Kenworthy, J.; Marinova, D. Higher Density Environments and the Critical Role of City Streets as Public Open Spaces. Sustainability 2020, 12, 8896. [CrossRef]

20. Tsoka, S.; Tsikaloudaki, K.; Theodosiou, T.; Bikas, D. Urban Warming and Cities' Microclimates: Investigation Methods and Mitigation Strategies-A Review. Energies 2020, 13, 1414. [CrossRef]

21. Czaja, M.; Kołton, A.; Muras, P. The Complex Issue of Urban Trees-Stress Factor Accumulation and Ecological Service Possibilities. Forests 2020, 11, 932. [CrossRef]

22. Jim, C. Outstanding remnants of nature in compact cities: Patterns and preservation of heritage trees in Guangzhou city (China). Geoforum 2005, 36, 371-385. [CrossRef]

23. Yaacob, W.N.A.H.W.A.; Hassan, N.; Hassan, K.; Nayan, N.M. The Morphology of Heritage Trees in Colonial Town: Taiping Lake Garden, Perak, Malaysia. Procedia Soc. Behav. Sci. 2016, 222, 621-630. [CrossRef]

24. Jim, C.Y. Multipurpose census methodology to assess urban forest structure in Hong Kong. Arboric. Urban For. 2008, 34, 366-378.

25. Lin, H.-W.; Chuang, Y.-C.; Liu, W.-Y. Assessing the economic value of an iconic urban heritage tree. For. Policy Econ. 2020, 118, 102216. [CrossRef]

26. Mundoli, S.; Harini, N. Heritage Trees of Urban India: Importance and Their Protection; Azim Premji University: Bengaluru, India, 2020.

27. Department of National Parks, Wildlife and Plant Conservation. Pracharat Forest Park for the Happiness of Thai People; Ministry of Natural Resources and Environment: Bangkok, Thailand, 2018.

28. Department of Cultural Promotion. Trees of Siam: Treasures of the Land under the Royal Benevolence of His Majesty the King; Ministry of Culture: Bangkok, Thailand, 2018.

29. Sommeechai, M.; Wachrinrat, C.; Dell, B.; Thangtam, N.; Srichaichana, J. Ecological Structure of a Tropical Urban Forest in the Bang Kachao Peninsula, Bangkok. Forests 2018, 9, 36. [CrossRef]

30. Thaiutsa, B.; Puangchit, L.; Kjelgren, R.; Arunpraparut, W. Urban green space, street tree and heritage large tree assessment in Bangkok, Thailand. Urban For. Urban Green. 2008, 7, 219-229. [CrossRef]

31. Meteorological Department. The Climate of Thailand; Meteorological Development Bureau: Bangkok, Thailand, 2020.

32. Chirathivat, S.; Cheewatrakoolpong, K. Thailand's Economic Integration with Neighboring Countries and Possible Connectivity with South Asia; Asian Development Bank Institute: Tokyo, Japan, 2015.

33. Jim, C.; Zhang, H. Species diversity and spatial differentiation of old-valuable trees in urban Hong Kong. Urban For. Urban Green. 2013, 12, 171-182. [CrossRef]

34. Marine Department. Regulations: Rules for Caution and Signing of Land Boundaries; Ministry of Transport: Bangkok, Thailand, 2015.

35. British Columbia Ministry of Forest. Techniques and Procedures for Collecting Preserving Processing and Storing Botanical Specimens; Province of British Columbia, Ministry of Forests Research Program: Victoria, BC, Canada, 1996.

36. Forest Herbarium. Thai Plant Names: Tem Smitinand; Department of National Parks, Wldlife and Plant Conservation: Bangkok, Thailand, 2014.

37. Omayio, D.; Mzungu, E. Modification of Shannon-Wiener Diversity Index towards Quantitative Estimation of Environmental Wellness and Biodiversity Levels under a Non-comparative Scenario. J. Environ. Earth Sci. 2019, 9, 46-57. [CrossRef]

38. Pielou, E.C. The measurement of diversity in different types of biological collections. J. Theor. Biol. 1966, 13, 131-144. [CrossRef]

39. Lai, P.Y.; Jim, C.; Da Tang, G.; Hong, W.J.; Zhang, H. Spatial differentiation of heritage trees in the rapidly-urbanizing city of Shenzhen, China. Landsc. Urban Plan. 2018, 181, 148-156. [CrossRef]

40. Hill, M.O.; Gauch, H.G. Detrended Correspondence Analysis: An Improved Ordination Technique. Classif. Ordination 1980, 42, 47-58. [CrossRef]

41. Eilertsen, O.; Okland, R.H.; Okland, T.; Pedersen, O. Data manipulation and gradient length estimation in DCA ordination. J. Veg. Sci. 1990, 1, 261-270. [CrossRef] 
42. Parnell, J.; Waldren, S. Detrended correspondence analysis in the ordination of data for phenetics and cladistics. TAXON 1996, 45, 71-84. [CrossRef]

43. Jakubínský, J.; Prokopová, M.; Raška, P.; Salvati, L.; Bezak, N.; Cudlín, O.; Cudlín, P.; Purkyt, J.; Vezza, P.; Camporeale, C. Managing floodplains using nature-based solutions to support multiple ecosystem functions and services. WIREs Water 2021, 8, e1545. [CrossRef]

44. Durr, P. The biology, ecology and agroforestry potential of the raintree, Samanea saman (Jacq.) Merr. Agrofor. Syst. 2001, 51, 223-237. [CrossRef]

45. Kamyo, T.; Asanok, L. Modeling habitat suitability of Dipterocarpus alatus (Dipterocarpaceae) using MaxEnt along the Chao Phraya River in Central Thailand. For. Sci. Technol. 2019, 16, 1-7. [CrossRef]

46. Asanok, L.; Kamyo, T.; Marod, D. Maximum entropy modeling for the conservation of Hopea odorata in riparian forests, central Thailand. Biodiversitas J. Biol. Divers. 2020, 21, 4663-4670. [CrossRef]

47. Imai, N.; Furukawa, T.; Tsujino, R.; Kitamura, S.; Yumoto, T. Factors affecting forest area change in Southeast Asia during 1980-2010. PLoS ONE 2018, 13, e0197391. [CrossRef] [PubMed]

48. Royal Forest Department. Royal Decree on Restricted Timber Species B.E. 1987; Chatuchak: Bangkok, Thailand, 1987.

49. Chantarasuwan, B.; Berg, C.C.; Van Welzen, P.C. A Revision of Ficus Subsection Urostigma (Moraceae). Syst. Bot. 2013, 38, 653-686. [CrossRef]

50. Sitaramam, V.; Jog, S.R.; Tetali, P. Ecology of Ficus religiosa accounts for its association with religion. Curr. Sci. 2009, 97, 637-640.

51. Yotapakdee, T.; Asanok, L.; Kamyo, T.; Norsangsri, M.; Karnasuta, N.; Navakam, S.; Kaewborisut, C. Benefits and Value of Big Trees in Urban Area: A Study in Bang Kachao Green Space, Thailand. Environ. Nat. Resour. J. 2018, 17, 33-43. [CrossRef]

52. Larsen, K.; Larsen, S.S. Additions to the Leguminosae of Thailand; Department of National Parks, Wldlife and Plant Conservation: Bangkok, Thailand, 1995.

53. Chamchumroon, V.; Suphuntee, N.; Tetsana, N.; Poopath, M.; Tanikkool, S. Threatened Plants in Thailand; Department of National Parks, Wldlife and Plant Conservation: Bangkok, Thailand, 2017.

54. Kowarik, I.; Fischer, L.K.; Kendal, D. Biodiversity Conservation and Sustainable Urban Development. Sustainability 2020, $12,4964$. [CrossRef]

55. McKinney, M.L. Effects of urbanization on species richness: A review of plants and animals. Urban Ecosyst. 2008, 11, 161-176. [CrossRef]

56. Dafni, A. On the typology and the worship status of sacred trees with a special reference to the Middle East. J. Ethnobiol. Ethnomed. 2006, 2, 26. [CrossRef] [PubMed]

57. Darlington, S.M. The Ordination of a Tree: The Buddhist Ecology Movement in Thailand. Ethnology 1998, 37. [CrossRef]

58. Kolimenakis, A.; Solomou, A.; Proutsos, N.; Avramidou, E.; Korakaki, E.; Karetsos, G.; Maroulis, G.; Papagiannis, E.; Tsagkari, K. The Socioeconomic Welfare of Urban Green Areas and Parks; A Literature Review of Available Evidence. Sustainability 2021, 13, 7863. [CrossRef]

59. Wajchman-Świtalska, S.; Zajadacz, A.; Lubarska, A. Therapeutic Functions of Forests and Green Areas with Regard to the Universal Potential of Sensory Gardens. Environ. Sci. Proc. 2020, 3, 8. [CrossRef]

60. Krzeptowska-Moszkowicz, I.; Moszkowicz, Łukasz; Porada, K. Evolution of the Concept of Sensory Gardens in the Generally Accessible Space of a Large City: Analysis of Multiple Cases from Kraków (Poland) Using the Therapeutic Space Attribute Rating Method. Sustainability 2021, 13, 5904. [CrossRef]

61. Brookes, A. Preventing death and serious injury from falling trees and branches. J. Outdoor Environ. Educ. 2007, 11, 50-59. [CrossRef]

62. Badrulhisham, N.; Othman, N. Knowledge in Tree Pruning for Sustainable Practices in Urban Setting: Improving Our Quality of Life. Procedia Soc. Behav. Sci. 2016, 234, 210-217. [CrossRef]

63. Roman, L.; Catton, I.; Greenfield, E.; Pearsall, H.; Eisenman, T.; Henning, J. Linking Urban Tree Cover Change and Local History in a Post-Industrial City. Land 2021, 10, 403. [CrossRef]

64. Santisuk, T. Forest of Thailand; Department of National Parks, Wldlife and Plant Conservation: Bangkok, Thailand, 2006.

65. Marcotullio, P. Asian urban sustainability in the era of globalization. Habitat Int. 2001, 25, 577-598. [CrossRef]

66. Koodsela, W.; Dong, H.; Sukpatch, K. A Holistic Conceptual Framework into Practice-Based on Urban Tourism Toward Sustainable Development in Thailand. Sustainability 2019, 11, 7152. [CrossRef]

67. Wang, J.; Farooq, T.H.; Aslam, A.; Shakoor, A.; Chen, X.; Yan, W. Non-targeted metabolomics reveal the impact of phenanthrene stress on root exudates of ten urban greening tree species. Environ. Res. 2021, 196, 110370. [CrossRef]

68. Ortega-Álvarez, R.; Rodríguez-Correa, H.A.; Fors, I.M.G. Trees and the City: Diversity and Composition along a Neotropical Gradient of Urbanization. Int. J. Ecol. 2011, 2011, 1-8. [CrossRef]

69. Lindenmayer, D.B.; Laurance, W.F. The ecology, distribution, conservation and management of large old trees. Biol. Rev. 2016, 92, 1434-1458. [CrossRef]

70. Vogt, J.; Hauer, R.; Fischer, B. The Costs of Maintaining and Not Maintaining the Urban Forest: A Review of the Urban Forestry and Arboriculture Literature. Arboric. Urban For. 2015, 41, 293-323. [CrossRef]

71. Han, Z.-Y.; Chang, Y.Y. Beijing Resident's Preferences of Ecosystem Services of Urban Forests. Forests 2020, 12, 14. [CrossRef] 